\title{
ANALISIS REVENUE SHENANIGANS PADA PERUSAHAAN PT GARUDA INDONESIA (PERSERO) Tbk
}

\author{
Natalis Christian', Junnestine ${ }^{\mathbf{2}}$ \\ ${ }^{1,2}$ Universitas Internasional Batam \\ Batam, Indonesia \\ natalis.christian@uib.ac.id ${ }^{1}, 1842004 . j u n n e s t i n e @ u i b . e d u^{2}$
}

\begin{abstract}
Revenue shenanigans was actions that present false financial statements or manipulated reports with several techniques was included recorded income at the beginning, recorded fake income, diverted income to the next period. This study utilized a qualitative approach in explaining the phenomena that occured in detail and the source of the data used was secondary data. The purpose of this paper was to analyze the revenue shenanigans that had been violated by PT Garuda Indonesia Tbk. The result of this study proved that PT Garuda Indonesia Tbk had made the 1st revenue shenanigans in manipulating its financial statements.
\end{abstract}

Keyword: Revenue Shenanigans, Garuda Indonesia, Manipulate Report

\section{PENDAHULUAN}

Revenue shenanigans melakukan tindakan memberikan informasi kinerja dan kondisi keuangan yang bersifat palsu pada laporan keuangan. Revenue shenanigans ini sering secara tidak langsung telah dilakukan ketika perusahaan melakukan manipulasi pada berbagai kondisi perusahaan.

Revenue shenanigans dapat mempengaruhi perusahaan dalam hal investasi bagi investor dimana akan memberikan dampak yang tidak baik terhadap harga saham dan prospek perusahaan kedepannya, meskipun revenue shenanigans dapat merupakan salah satu pelanggaran dalam akuntansi. Dampak buruk yang diberikan dapat membuat sebuah perusahaan menjadi dalam kondisi bangkrut (Jamieson et al., 2019; Sakti et al., 2020). Banyaknya kasus perusahaan yang sering memanipulasikan pendapatan perusahaan dengan mengecilkan maupun memperbanyak pendapatan serta beban, maupun akun akuntansi perusahaan lainnya.

Adanya kasus perusahaan di Indonesia yang melakukan manipulasi keuangan dan dapat dikatakan perusahaan tersebut telah melakukan salah satu dari revenue shenanigans. Perusahaan Garuda Indonesia pernah melakukan pelanggaran tersebut dimana dengan melaporkan pendapatan palsu pada laporan keuangan perusahaannya, yang dapat membuat para pengguna laporan keuangannya menjadi salah dalam mengambil keputusan untuk perusahaan (Jamieson et al., 2019).

Berdasarkan kasus yang terdapat pada perusahaan Garuda Indonesia, maka penulis bermaksud melakukan analisis terhadap kasus manipulasi laporan keuangan Garuda yang terjadi pada tahun 2018 dan 
mengetahui revenue shenanigans yang telah dilanggar oleh Garuda.

\section{Shenanigans 1: Mengakui pendapatan} terlalu cepat atau mengakui adanya pendapatan sebelum waktunya.

Menurut Schilit \& Perler (2010), terdapat beberapa teknik untuk mengungkap tidak atau kurang melaporkan kewajiban.

a. Mengakui pendapatan sebelum menyelesaikan segala kewajiban berdasarkan kontrak. Para eksekutif dapat memperpanjang bulan terakhir kuartal hingga 35 hari dan kontrak penjualan yang sudah usang serta dipalsukan untuk mengelabui auditor dan investor mereka agar mempercayai pertumbuhan penjualan fiktif perusahaan dengan untuk mendapatkan bonus dan opsi saham. Perusahaan yang memperpanjang tanggal akhir kuartal akan sangat mencurigakan, hal ini dikarenakan sistem tidak akan secara sendirinya mempercepat pendapatan secara tidak tepat dengan memperpanjang tanggal akhir kuartal.

b. Mengakui pendapatan yang lebih daripada pekerjaan yang tertera di kontrak. Perusahaan juga akan menarik penjualan lisensi yang sebenarnya tidak akan diperoleh dimasa yang akan datang, karena semua pendapatan lisensi dicatat pada awal kontrak dan akan dicatat sebagai piutang jangka panjang di neraca.

c. Mengakui pendapatan sebelum pengiriman barang atau sebelum barang diterima dengan sah oleh konsumen. Metode ini sering mengakibatkan kontroversi karena melibatkan masalah dimana entitas melakukan penagihan kepada pelanggan untuk suatu produk tetapi pelanggan belum menerima produk tersebut. Pada pendekatan ini, penjual menagih pelanggan dan mengakui pendapatan dengan melakukan penahanan pada produk. Dalam keadaan apa pun, pengakuan awal pendapatan tidak dapat terjadi jika pengaturan tersebut diprakarsai oleh penjual untuk kepentingan penjual.

d. Mengakui pendapatan suatu transaksi meskipun konsumen tidak wajib melakukan pembayaran. Penjual mempercepat pengakuan pendapatan ketika pembeli tidak memiliki kemampuan untuk membayar (pembayaran tetap tidak pasti) atau ketika penjual secara agresif mendorong penjualan dengan tidak meminta pelanggan untuk membayar setelah penjualan (pembayaran tetap tidak diperlukan). 


\section{Shenanigans 2: Mengakui adanya pendapatan palsu sebagai pendapatan.}

Menurut Schilit \& Perler (2010), terdapat empat teknik yang digunakan perusahaan untuk menciptakan pendapatan palsu:

a. Mengakui penjualan yang tidak memiliki substansi ekonomis. Teknik ini hanya menunjukkan skema yang memiliki "tampilan dan nuansa" dari penjualan yang sah, namun pada kenyataannya tidak memiliki substansi ekonomi. Dalam transaksi ini, pelanggan tidak berkewajiban untuk menyimpan atau membayar produk, atau tidak ada materi yang benar-benar ditransfer dari awal.

b. Mengakui pendapatan dari transaksi yang tidak memiliki proses panjang yang wajar. Dengan mengakui pendapatan dari transaksi yang tidak memiliki substansi ekonomi dan tidak melalui semua proses yang wajar akan di anggap tidak sah karena transaksi tersebut tidak nyata. Sebagian besar transaksi pihak terkait yang tidak memiliki pertukaran yang wajar menghasilkan pendapatan yang meningkat, dan seringkali palsu. Jika penjual dan pelanggan berafiliasi, maka kualitas pendapatan penjual dapat dicurigai.

c. Mengakui pendapatan atas penerimaan dari transaksi non-pendapatan.
Pendapatan palsu muncul dari kesalahan klasifikasi uang tunai yang diterima dari aktivitas non-pendapatan. Beberapa arus masuk terkait dengan aktivitas pendanaan (pinjaman dan penerbitan saham), dan lainnya dengan penjualan bisnis atau berbagai aset. Perusahaan yang mengakui pendapatan atau pendapatan dari sumber non-pendapatan dianggap salah karena melaporkan pendapatan palsu untuk meningkatkan pendapatan.

d. Mengakui pendapatan dari transaksi namun dengan jumlah yang berlebihan atau tidak sesuai. Pendapatan yang berlebihan atau menyesatkan dihasilkan dari penggunaan metodologi yang tidak tepat untuk mengakui pendapatan atau pendapatan kotor untuk membuat perusahaan memiliki pendapatan yang jauh lebih besar dari yang sebenarnya.

\section{Shenanigans 6: Menggeser Arus}

\section{Pendapatan untuk Periode Selanjutnya.}

Menurut Schilit \& Perler (2010), pada shenanigans ini bertolak belakang dengan shenanigans ke-1 dan shenanigans ke-2, dimana yang dijelaskan mengenai membesar-besarkan laba dan pada shenanigans ke-6 justru mengecilkan laba.

a. Membuat cadangan dan menjadikannya sebagai pendapatan di periode selanjutnya. Perusahaan yang memiliki 
pendapatan yang tinggi biasanya tidak melaporkan semua pendapatannya, namun menyimpan sebagian untuk dimasukan ke cadangan ataupun dicatat ke pendapatan diterima dimuka pada periode tersebut. Hal ini tidak akan terdeteksi oleh auditor bahkan terdapat kemungkinan kecil auditor untuk menanyakan hal tersebut. Pendapatan diterima dimuka akan dicatat ke pendapatan pada saat dibutuhkan diperiode selanjutnya.

b. Akuntansi derivatif yang tidak tepat untuk memperlancar pendapatan. Investor harus berhati-hati ketika perusahaan melaporkan keuntungan besar dari aktivitas lindung nilai, karena lindung nilai ini merupakan aktivitas perdagangan spekulatif yang tidak dapat diandalkan dan dapat dengan mudah menghasilkan kerugian besar di periode mendatang. Selain itu, investor harus memperhatikan lindung nilai yang menghasilkan keuntungan jauh melebihi kerugian aset atau liabilitas yang mendasarinya.

c. Membuat cadangan sehubungan dengan akuisisi dan menjadikan cadangan tersebut menjadi pendapatan di periode selanjutnya. Teknik ini dilaksanakan pada perusahaan yang melakukan akuisisi. Perusahaan akuisisi sulit menganalisis secara langsung seperti cash-flownya sehingga perusahaan yang melakukan akuisisi mungkin akan menahan sebagian pendapatan yang diperoleh sebelum kesepakatan ditutup sehingga pengakuisisi dapat mencatatnya di periode selanjutnya.

d. Mencatat penjualan periode saat ini di periode selanjutnya. Teknik ini tidak jauh berbeda dengan teknik sebelumnya dimana teknik ini menahan laba pada periode ini dan dicatat saat tutup buku atau periode selanjutnya. Hal ini dikarenakan manajemen sudah mencapai target pada periode tersebut sehingga menahan sebagian laba untuk di periode selanjutnya. Teknik ini membuat para investor tersesat dalam mengambil keputusan (Schilit \& Perler, 2010).

\section{METODE PENELITIAN}

\section{Jenis Penelitian}

Penelitian ini memanfaatkan pendekatan kualitatif yang merupakan suatu metode penelitian dimana data yang digunakan sesuai maksud serta tujuan penelitian dengan teknik pengumpulan yang berbeda sehingga mampu mendapatkan sumber data yang sama. Studi kasus menjadi penelitian kualitatif yang dilakukan yang dapat menjelaskan suatu fenomena secara detail dengan melakukan pengumpulan data secara lengkap. 


\section{Objek Penelitian}

PT Garuda Indonesia (Persero) Tbk akan menjadi objek dalam menganalisis tindakan kecurangan yang telah dilakukan oleh perusahaan.

\section{Metode Penelitian}

Metode yang digunakan pada penelitian ini yakni memanfaatkan data sekunder, dimana tahap awal adalah mengumpulkan data terlebih dahulu dan kemudian diklasifikasikan serta menganalisis sehingga dapat memberikan gambaran secara aktual dan akurat mengenai penelitian yang dilakukan. Data pada Garuda bisa diakses pada website Garuda ataupun melalui www.idx.com.

\section{PEMBAHASAN}

PT Garuda Indonesia (Persero) Tbk merupakan sosok maskapai penerbangan yang dibanggakan oleh Indonesia yang mana memiliki tanggung jawab besar terhadap setiap pemangku kepentingannya.

Setiap perusahaan tentu memiliki keinginan untuk menghasilkan laporan keuangan yang cantik atau memiliki kinerja keuangan yang baik, namun Garuda mempercantik laporannya dengan cara tidak lazim atau melanggar berbagai peraturan yang ada sehingga Garuda sudah melakukan revenue shenanigans, buktinya dapat dilihat pada laporan tahunan Garuda tahun 2018.

Pada laporan tahun 2018, Garuda menghasilkan laba sebesar USD 809,84 ribu sedangkan pada tahun 2017, perusahaan mencatat rugi usaha sebesar USD 213,38 juta. Jika merujuk pada laporan keuangan terdapat kejanggalan, dimana terdapat akun pendapatan lain-lain senilai USD 278,81 juta yang mana terdapat kenaikan hampir 14 kali dari pendapatan lain-lain tahun 2017.

\section{Gambar 1. Pendapatan lain-lain bersih}

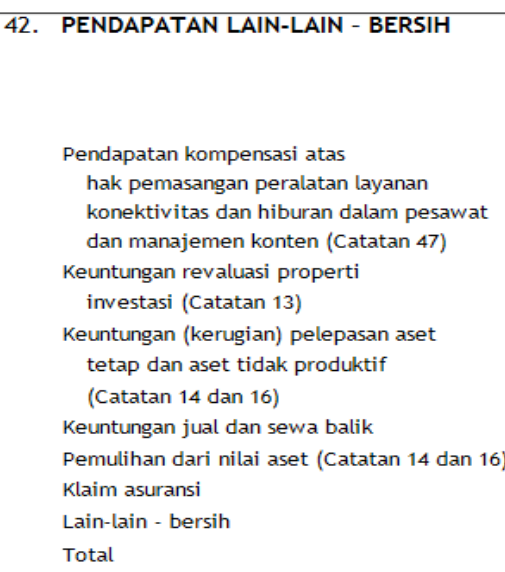

Pendapatan kompensasi atas

hak pemasangan peralatan layanan konektivitas dan hiburan dalam pesawat

dan manajemen konten (Catatan 47) Keuntungan revaluasi properti

investasi (Catatan 13)

Keuntungan (kerugian) pelepasan aset

tetap dan aset tidak produktif

(Catatan 14 dan 16)

Keuntungan jual dan sewa balik

Pemulihan dari nilai aset (Catatan 14 dan 16)

Klaim asuransi

Lain-lain - bersih

Total
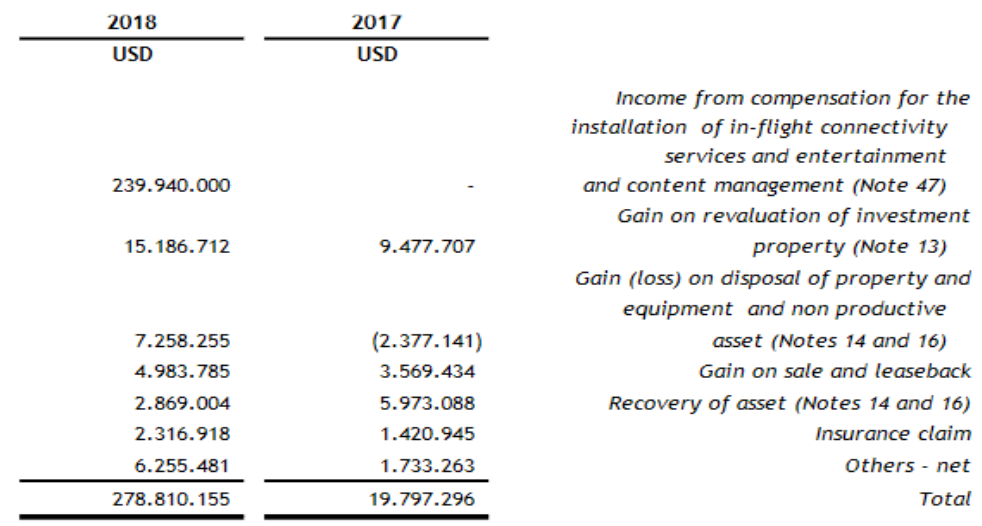

Sumber: Laporan Tahunan PT Garuda Indonesia, 2018 
Pada gambar 1 merupakan rincian lebih dalam mengenai pendapatan lain-lain Garuda, dimana terdapat pendapatan atas layanan konektivitas dan hiburan sebesar USD 239,94 juta. Transaksi pendapatan ini melibatkan suatu perusahaan yang bernama PT. Mahata Aero Teknologi. Perusahaan ini melakukan kontrak kerja sama dengan pihak Garuda pada tanggal 31 Oktober 2018 dalam mengadakan layanan wifi dan hiburan dalam pesawat. Adapun rincian pembayaran dari Mahata yakni sebesar USD 131,94 juta untuk pemasangan layanan konektivitas sebanyak 153 pesawat, hak hiburan dan manajemen konten sebesar USD 80 juta sebanyak 99 pesawat dan USD 28 juta sebagai insentif dari PT. Sriwijaya Air. Kontrak perjanjian antara Garuda dengan Mahata ini berlaku selama 15 tahun, pembayaran yang akan dibayar oleh pihak Mahata sebesar USD 239,94 juta dicatat sebagai pendapatan lainlain pada laporan tahunan 2018.

Peningkatan laba perusahaan mengakibatkan terjadinya polemik yakni dua komisaris Garuda, Chaerul Tanjung dan Dony Oskaria mengajukan keberatan dalam mengakui laporan tahunan 2018, sebab terdapat pendapatan dari pihak Mahata yang seharusnya tidak diakui oleh perusahaan, karena pembayaran dari Mahata belum masuk ke kas perusahaan (Pratiwi, 2019). Perusahaan Garuda mempunyai banyaknya kejanggalan yang dimana berubahnya beberapa kali kontrak maupun pendapatan akrual perusahaan. Tidak hanya itu, manajemen Garuda yakin bahwa perusahaan dalam menyusun laporan telah menyesuaikan dengan standar akuntansi dan bersikeras tidak akan mengaudit ulang hingga akhirnya kasus ini menjangkau hingga otoritas keuangan dan perusahaan diminta untuk mengkaji ulang laporan karena terbukti perusahaan melakukan shenanigans.

Diantara 3 revenue shenanigans yang telah dibahas, Garuda telah melakukan shenanigans ke-1, artinya perusahaan mencatat pendapatan terlalu dini sehingga laba perusahaan meningkat. Manajemen Garuda menganggap bahwa laporan yang disusun telah mengikuti standar akuntansi yang ada dan bersikeras tidak akan mengaudit ulang laporan. Alasan pendapatan dari pihak Mahata dicatat karena perusahaan menerapkan pencatatan akrual, artinya pendapatan dicatat meskipun kas belum diterima sehingga manajemen plat merah ini mengasumsikan bahwa pendapatan teruntuk 15 tahun ke depan boleh diakui langsung pada tahun 2018 sebagai pendapatan. Dari pengakuan ini, pencatatan menggunakan 
akrual yang diasumsikan perusahaan sudah benar, namun yang menjadi masalah adalah metode pencatatan akrual yang dimaksud pada Pernyataan Standar Akuntansi Keuangan (PSAK) 23 terdapat ketentuan bahwa pendapatan dapat diakui apabila jumlah dari keseluruhan pendapatan dapat diperkirakan secara andal, kemudian terwujudnya manfaat ekonomi bagi entitas, biaya serta penyelesaian transaksi dapat diestimasi secara andal (Ikatan Akuntan Indonesia, 2015). Berdasarkan standar tersebut, maka Garuda tidak boleh mengakui suatu transaksi yang belum mendatangkan pengorbanan ekonomi dan belum ada nominal kas yang dikantongin perusahaan.

Meskipun pada sisi laba rugi perusahaan telah meraih keuntungan, namun pada sisi arus kas perusahaan telah mengalami kerugian yang cukup besar. Hal tersebut dikarenakan adanya kewajiban atas Pajak Penghasilan (PPh) dan Pajak Pertambahan Nilai (PPN) yang harus dibayar oleh perusahaan. Jika perusahaan tidak mencatat pendapatan dari Mahata maka beban pajak tersebut belum menjadi kewajiban perusahaan.

Akibat dari manipulasi yang dilakukan oleh perusahaan, Otoritas Jasa Keuangan (OJK) memutuskan beberapa hal, yakni pada tanggal 28 Juni 2019, Garuda diminta untuk memperbaiki dan mengkaji ulang laporan tahunan 2018 dengan paling lambat melaporkannya pada tanggal 26 Juli 2019. Kemudian sanksi dikenakan kepada seluruh direksi, dewan komisaris (terkecuali dua dewan komisaris yang tidak menandatangani laporan keuangan), dan atas rekayasa laporan tahunan 2018 dengan nominal sebesar Rp. 100 juta kepada masing masing pihak yang berkaitan. Sanksi juga dikenakan kepada auditor dan Kantor Akuntan Publik (KAP) yang terbukti melakukan kesalahan dalam penyajian.

\section{KESIMPULAN DAN SARAN}

Laporan keuangan PT Garuda Indonesia (Persero) Tbk tahun 2018 dinilai tidak memenuhi kaidah penyajian laporan keuangan. Di dalam laporan keuangan tahun 2018 tersebut, tercatat pendapatan atas layanan konektivitas dan hiburan sebesar USD 239,94 juta dari PT. Mahata Aero Teknologi yang seharusnya masih menjadi piutang.

Dengan mencatat pendapatan terlalu dini, Garuda telah melakukan shenanigans ke-1 dari 3 revenue shenanigans yang ada. Dengan shenanigans yang dilakukan, perusahaan telah meningkatkan laba pada 
tahun 2018. Namun, berdasarkan PSAK 23

tepatnya di paragraf 14 yang menyatakan pendapatan atas suatu transaksi akan terakui saat seluruh kondisi dipenuhi. Kondisi yang berarti risiko dan manfaat ekonomi telah beralih sepenuhnya kepada pembeli. Berdasarkan standar tersebut, maka PT Garuda Indonesia (Persero) Tbk tidak boleh mengakui transaksi tersebut karena kerja sama antara kedua perusahaan tersebut dinyatakan akan berlangsung selama 15 tahun sehingga pada akhir kasus, Garuda diperintahkan untuk mengkaji ulang laporan keuangan tahun 2018 oleh OJK. Selain itu, sanksi denda juga dikenakan kepada Garuda sendiri bersama seluruh anggota direksi dan komisarisnya. Sanksi berupa pembekuan izin juga dikenakan kepada Kasner Sirumapea selaku auditor laporan keuangan tahun 2018 Garuda.

Untuk menghindari terjadinya kasus serupa, Garuda seharusnya mengungkapkan kepada publik mengenai alur dari kasus tersebut di mana laporan keuangan tahun 2018 yang harusnya rugi menjadi laba. Pihak
KAP juga perlu melakukan pengecekan secara teliti terhadap setiap transaksi sehingga memenuhi standar akuntansi keuangan.

\section{DAFTAR PUSTAKA}

Ikatan Akuntan Indonesia. (2015). Pernyataan Standar Akuntansi Keuangan. Jakarta: Ikatan Akuntan Indonesia.

Jamieson, D., Awolowo, I. F., Garrow, N., Winfield, J., \& Bhaiyat, F. (2019). Revenue shenanigans: The importance of anti-fraud education. Journal of Governance and Regulation, Vol. 8, No. 3, h. 58-63.

Pratiwi Rika, H. (2019, April 24). Dua Komisaris Garuda Indonesia Tolak Laporan Keuangan. Diakses tanggal 9 Mei 2021 dari https://www.cnninones ia.com/ekonomi/20190424155941-92-3 89264/dua-komisaris-garuda-indonesia tolak-laporan-keuangan.

Sakti, E., Tarjo, Prasetyono, \& Riskiyadi, M. (2020). Detection of Fraud Indications in Revenue Statements Using Revenue Shenanigans. Asia Pacific Fraud Journal. Vol. 5, No. 2, h. 277-287.

Schilit, H. M. \& Perler, J. (2010). Revenue Shenanigan (3rd ed). New York: Mc Graw Hill. Diakses tanggal 9 Mei 2021 dari: http://digilib.stiem.ac.id:8080/js pui/bitstream/123456789/230/1/Financia $1 \% 20$ Sh enanigans.pdf. 